\title{
Clashing Geostrategic Choices in East Asia, 2009-2015: Re-balancing, Wedge Strategy, and Hedging
}

\author{
Jahyun Chun and Yangmo Ku
}

This study aims to analyze a reshaping of the geopolitical dynamics in the East Asian region during the 2009-2015 period, which was mainly derived from the rapid growth of Chinese power. What strategies did the three major powers in East Asia-the U.S., China, and South Korea-adopt to maintain and promote their own and their collective interests? What impact did these strategies bring to East Asian international relations? What implications do these strategies have for the future East Asian regional order? In response to these questions, this article mainly argues that during the 2009-2015 period, the U.S., China, and South Korea took three geostrategic choices-rebalancing, wedge strategy, and hedging, respectively. In particular, this study creates the concept of a historical alliance between China and South Korea against their former common adversary, Japan. As part of China's wedge strategy, the formation of such historical alliance played a role in weakening the U.S.-ROK-Japan security triangle. These clashing strategies have produced unstable conditions in East Asia, including intensifying U.S.-China rivalry, continuity of China-Japan and Japan-ROK tensions, and an ambivalent South Korean stance. A most important measure to alleviate these volatile conditions is for the U.S. and China to not intensify their rivalry, and instead maximize mutual cooperation in dealing with various challenging global issues, such as pandemics, global economic/ financial instability, climate change, nuclear proliferation, and war on terror. This article also suggests that under the condition of the intensifying U.S.-China rivalry, South Korea should

* Jahyun Chun (jhreine@yonsei.ac.kr) is Associate Professor at Yonsei University, Department of International Relations and EIC in Mirae campus. Chun's research interests include international reconciliation and foreign policy in East Asia. Her publications appeared and will appear in International Studies Perspectives, Interventions: Post Colonial Studies, Japanese Journal of Political Science, Pacific Focus, International Journal, Asia Europe Journal, International Politics, and Handbook of Memory and Reconciliation (New York: Routledge, 2015).

** Yangmo Ku (yku@norwich.edu) is Associate Professor of Political Science and Associate Director of the Peace and War Center at Norwich University, USA. He received his Ph.D. in Political Science from the George Washington University and previously taught at the School of International Service at American University. His research focuses on East Asian security, US foreign policy, and the politics of memory and reconciliation in East Asia and Europe. He also serves as founding Editor of an academic journal titled Journal of Peace and War Studies and is often invited to teach intensive courses on the politics of the Korean Peninsula to US federal agency workers.

The Korean Journal of International Studies Vol.18, No.1 (April 2020), 33-57 
maintain a strategic ambiguity as opposed to hastily siding with one side.

Key Words: Geostrategic choices, Re-balancing, Wedge strategy, Historical alliance, Hedging, East Asia, U.S.-China rivalry

\section{INTRODUCTION}

The 2009-2015 period notably witnessed a reshaping of the geopolitical dynamics in East Asia, as the power of the People's Republic of China (hereafter, PRC or China) had grown rapidly. After the end of World War II, the United States, as a global superpower, maintained its hegemonic status in the East Asian region, thus designing the regional order to its own advantage. Based on its close security alliances with Japan and the Republic of Korea (hereafter, ROK or South Korea), the United States was able to satisfy its national interests by securing sea-lanes and promoting trade relationships with many Asian nations. Except for North Korea's rhetorically provocative actions, no country could dare to challenge the U.S. hegemony in the region.

However, the rise of China, which has gradually occurred since 1978, became a serious challenge to the U.S. hegemony in East Asia. Based on its rapid economic growth, the PRC has sought to expand its military power and promote its political and economic influence in the region. The 2008-2009 global financial crisis, which started in the U.S., contributed greatly to the emergence of perceptions among Chinese elites that U.S. regional power had declined significantly (Scobell and Harold 2013). Unlike the U.S., China was able to handle the crisis without major economic disruption due to its notable increase in domestic investment and huge foreign currency reserves. In addition, Chinese nationalism arguably reached its peak because of the successful hosting of the 2008 Beijing Olympics (Saunders 2014). Thus, from 2010 onward, China has been more assertive in dealing with the South China Sea maritime disputes and the sovereignty debate of the Senkaku/Diaoyu islands (Christensen 2011; Johnston 2013; Chen and Pu 2014). ${ }^{1}$ These disagreements have led to the perception among China's neighbors that it seeks to change the status quo in the Asian regional order; this has led to significantly heightened military tensions with its neighbors, particularly Vietnam, the Philippines, and Japan, as well as the United States.

Given these changing geopolitical circumstances, what strategies did the three

${ }^{1}$ Scholars have debated over the degree of China's assertiveness, nevertheless, they have reached the consensus that China's attitude toward maritime disputes has been notably assertive since 2009. 
major powers in East Asia-the U.S., China, and South Korea ${ }^{2}$-adopt to maintain and promote their own and their collective interests? What impact did these strategies bring to East Asian international relations? What implications do these strategies have for the future East Asian regional order? Are there any other effective policy measures that could lead to the maintenance and promotion of peace and stability in the region? In response to these questions, this article mainly argues that during the 2009-2015 period, the U.S., China, and South Korea took three geostrategic choices-rebalancing, wedge strategy, and hedging, respectively. These strategies have produced unstable conditions in East Asia, including intensifying US-China rivalry, continuity of China-Japan and Japan-ROK tensions, and an ambivalent South Korean stance. A most important measure to alleviate these volatile conditions is for the U.S. and China to not intensify their rivalry, and instead maximize mutual cooperation in dealing with various challenging global issues, such as pandemics, global economic/financial instability, climate change, nuclear proliferation, and war on terror.

In the subsequent sections, this article first addresses a brief historical trajectory of geostrategic choices made by the major East Asian powers in the wake of World War II. It then elucidates the concepts of rebalancing, wedge strategy, and hedging, which can properly explain the strategic configurations in the region during the 2009-2015 period. The following section examines the detailed policy measures of each nation, which constituted the three strategies. Finally, while exploring the impact of those strategies on East Asian international relations, the article provides policy recommendations for the three nations to enhance peace and stability in the region.

2 In this article, Japan is regarded as another major player in East Asia, but the country's strategic choice is not analyzed separately, as it has been largely similar to that of the United States. The US' military transformation during this period had a direct impact on its allies, especially on Japan, as the US regarded Japan as the cornerstone of its Asia Pacific security strategy. As a result, Japan's strategic moves took full advantage of the US' shift in security paradigm and accelerated the strengthening of the US-Japan strategic alliance. In other words, the key to Japan's diplomatic strategy was to strengthen their alliance with the US and to obtain the US' involvement (Kim 2015; Moon 2014; Sohn 2010). Chinese scholars criticize that Japan was able to devise tough policies towards China around this time such as the Senkaku dispute because Japan had cooperated with the U.S. to accommodate the US' security strategy (Dung 2013; Yang 2013). 


\section{A SNAPSHOT OF STRATEGIC CHOICES IN EAST ASIA}

During the Cold War period, geopolitical strategies that major East Asian countries adopted were quite simple. Before the split between the Soviet Union and the PRC in the 1960s, the U.S., Japan, and South Korea were allied to balance against the Soviet communist bloc, although the latter two nations had no directly allied relationship (Cha 1999). In the wake of the Soviet-Chinese rupture and the then U.S. President Richard Nixon's historic visit to China in 1972, the PRC loosely became aligned with the U.S.-ROK-Japan security triangle to deter the Soviet threat in East Asia (Tucker 2013). Thus, a balancing behavior was the main strategy of the major countries in the region during the Cold War era.

The demise of the Soviet Union in 1991 led to the rise of a sole superpower-the United States-in world politics, thus eliminating the need of the balancing strategy against the Soviet threat. Under this unipolar system, most East Asian nations adopted a strategy of bandwagoning with the U.S., rather than balancing against it. With support from the U.S. and Japan, China was able to achieve rapid economic development during the post-Cold War period, although the Tiananmen massacre in June 1989 caused a rupture in U.S.-China relations for a while.

After the 9/11 terrorist attacks in 2001, U.S. President George W. Bush and his administration adopted unilateralist foreign policies. Among them were withdrawing from the Anti-Ballistic Missile (ABM) treaty, occupying Iraq without the approval from the United Nations, and reaffirming its commitment to establish an ambitious ballistic missile defense system (Pape 2005). As Robert Pape argues, these unilateral national security strategies brought about "soft-balancing" measures, which imply "actions that do not directly challenge U.S. military preponderance but that use nonmilitary tools to delay, frustrate, and undermine aggressive unilateral U.S. military policies." (Pape 2005) Despite the emergence of such soft-balancing behavior, the unipolar system led by the U.S. arguably continued until the 2008-2009 global financial crisis. After the crisis, the U.S. hegemonic status in East Asia began to be challenged by the rapidly rising China. 
Figure 1. Clashing Geostrategic Choices in East Asia, 2009-2015

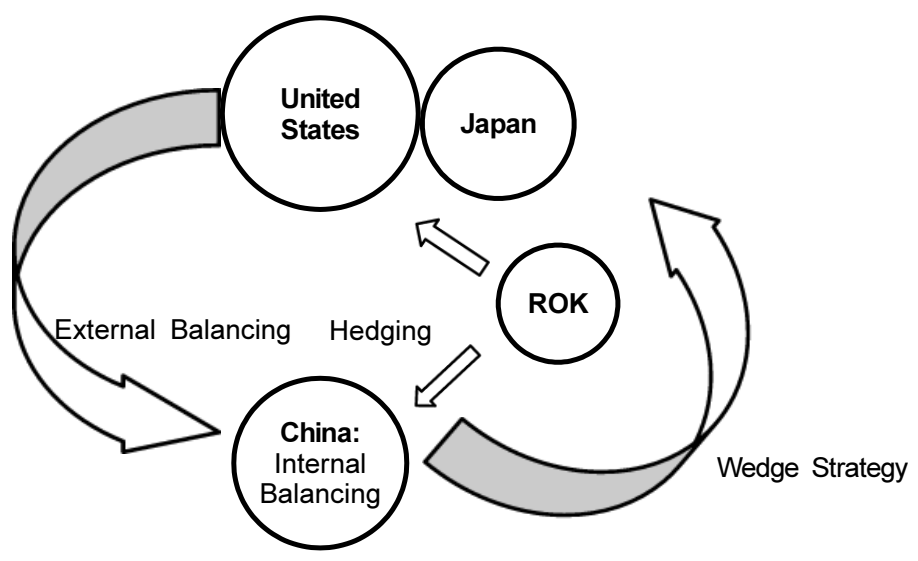

Accordingly, the 2009-2015 period saw the emergence of more complex geopolitical strategies in East Asia, as illustrated in Figure 1. The U.S. adopted a rebalancing strategy toward China, mainly an "external balancing” through strengthening its allied and partner relationships with many Asian nations, including Japan, the ROK, Australia, and the ASEAN countries. While seeking "internal balancing" through building powerful military capabilities, China employed a wedge strategy (as part of "external balancing") aimed at creating a chasm in the U.S.-ROK-Japan security triangle. Like many ASEAN countries, such as the Philippines and Thailand, the ROK implemented a hedging strategy, by working with both great powers-the U.S. and China-as opposed to siding with one of them evidently. Table 1 shows primary changes in geostrategic choices made by key East Asian powers since the end of World War II.

Table 1. Changes in Geostrategic Choices in East Asia

\begin{tabular}{|c|c|c|c|c|}
\hline & United States & Japan & China & South Korea \\
\hline $\begin{array}{c}\text { Cold War } \\
(1948-1972)\end{array}$ & $\begin{array}{l}\text { balancing } \\
\text { USSR \& PRC }\end{array}$ & $\begin{array}{l}\text { balancing } \\
\text { USSR \& PRC }\end{array}$ & balancing US & $\begin{array}{l}\text { balancing } \\
\text { USSR \& PRC }\end{array}$ \\
\hline $\begin{array}{l}\text { Cold War } \\
(1972-1991)\end{array}$ & balancing USSR & balancing USSR & balancing USSR & balancing USSP \\
\hline $\begin{array}{l}\text { Post-Cold War } \\
(1991-2008)\end{array}$ & $\begin{array}{l}\text { unilateralism as sole } \\
\text { superpower }\end{array}$ & bandwagoning & bandwagoning & bandwagoning \\
\hline $\begin{array}{l}\text { Post-Cold War } \\
(2009-2015)\end{array}$ & rebalancing PRC & rebalancing PRC & $\begin{array}{c}\text { balancing US } \\
\text { (wedging: historical } \\
\text { alliance) }\end{array}$ & hedging \\
\hline
\end{tabular}




\section{THE CONCEPTS OF REBALANCING, WEDGE STRATEGY, AND HEDGING}

The three analytical terms-rebalancing, wedge strategy, and hedging-adequately explain strategic configurations made in the region during the 2009-2015 period. A widely used definition of balancing is that weaker states seek to equalize the odds with a stronger state posing potential threats through building and implementing military capabilities and hard-power mechanisms (Waltz 2008; Brooks and Wohlforth 2008; Pape 2005). This definition, however, does not seem to be appropriate in describing the recent U.S. strategy in East Asia, because it should regard the U.S. as a weaker power than China. Although China's economic and military capabilities grew rapidly over the last three decades, it would be implausible to regard China as a more powerful nation than the U.S.

Thus, this article embraces a more nuanced definition of balancing, which means "any effort by a state to increase its relative power over a perceived threat" (Crawford 2008; Martin 2003). A balancing behavior encompasses both internal and external dimensions (Waltz 1979; Wohlforth, Kaufman and Little 2007). An external balancing means that a state seeks to increase its relative power over a perceived threat by forming an alliance with other nations. On the other hand, an internal balancing denotes that a state tries to strengthen its economic and military capabilities rather than relying on the capabilities of allies, thus augmenting its relative power over an external threat.

Timothy Crawford defines the wedge strategy as "a state's attempt to prevent, break up, or weaken a threatening or blocking alliance at an acceptable cost" (Crawford 2011). A successful wedge strategy provides the acting state (i.e. the divider) with the opportunity to diminish the number and strength of adversaries organized against it, as the strategy can turn opponents into neutrals or allies. As Crawford emphasizes, this wedge strategy can be a form of external balancing in the sense that a state increases its relative power by subtracting from the capabilities of threatening alliances. As a result, this concept rectifies a common bias toward balancing behavior that "states can only increase their relative power by adding to or aggregating their capabilities." (Crawford 2011)

In this context, we create the concept of a "historical alliance" as part of the wedge strategy. Japan's invasion of China in 1937 and colonial rule over Korea from 1910-1945 inflicted huge sufferings on both Chinese and Korean people. Given these common historical experiences, in the 2010s China sought to strengthen its ties with South Korea by steering the ROK to jointly criticize Japan's past misdeeds. The formation of such a historical alliance between China and South Korea against their common historical adversary, Japan could play an 
important role in driving a wedge in the U.S.-ROK-Japan security triangle, which is designed to check and balance the rise of China as well as the provocative North Korea. Thus, such a wedge strategy could significantly weaken the power of the U.S.-led coalition against China.

Hedging has several definitions in the existing literature (Park 2011). ${ }^{3}$ Appropriated from the financial term, hedging means that a state spreads its risk by pursuing two opposite policies. As Van Jackson (2014) notes, "hedging can be understood as a way of coping with uncertainty; it is a strategy of pursuing opposing or contradictory actions as a means of minimizing or mitigating downside risks associated with one or the other action." In international relations, states carry out two contradictory policy directions simultaneously (Hemmings 2013). This article thus defines hedging as "a practice of working with both sides." In other words, instead of putting all their eggs into one basket, a state diversifies security affiliations to maximize its own security. The next section addresses the detailed dynamics of these three strategies adopted by key East Asian powers during the 2009-2015 period.

\section{CLASHING GEOPOLITICAL STRATEGIES BETWEEN 2009 AND 2015}

The United States, a current hegemonic power in East Asia, has sought to rebalance the rapidly rising China, which could reshape the regional order set by the U.S. following the end of World War II. The rebalance demonstrates that the administration of President Barak Obama prioritized the Asia-Pacific region after the U.S. pullback from Iraq and Afghanistan. While focusing on an external balancing strategy, the United States has earnestly strengthened its alliances with Asian nations, including Japan, the ROK, Philippines, and Australia.

China adopted the wedge strategy in reaction to such U.S. efforts to strengthen its alliances with many Asian countries. China selectively accommodated a target -South Korea-while standing firm against other rivals, such as the U.S. and Japan. China attempted to make a "historical alliance" with the ROK against their common historical adversary, Japan. As a middle power, South Korea has pursued a hedging strategy between the U.S. and China. In response to the U.S. rebalancing against China and China's wedge strategy toward the U.S.-ROK-Japan security triangle, the ROK government has not completely skewed toward either of the two superpowers. Rather, the ROK has worked with both nations. Seoul has

3 For a detailed review of those various definitions, see Park (2011, 139-40). 
particularly cultivated its economic and "historical" cooperation with Beijing, while maintaining its close security ties with Washington. Thus, South Korea has been sandwiched in between the U.S.-Japan alliance and China.

\section{THE U.S. REBALANCING POLICY}

The rise of China steered the United States to enact a rebalancing "U.S. pivot to Asia” strategy in 2011. Following the September 11, 2001 terrorist attacks, the U.S. prioritized waging war against terrorism, a conflict that has consumed a large amount of American human and material resources in the Middle East. The 2008 financial crisis further weakened the U.S. economy, which had already been in decline due to its prolonged war efforts. On the other hand, China continued to develop its economy and eventually became the world's largest trading nation in 2013 , when it hit a record high trade volume of $\$ 4.16$ trillion, overtaking the U.S., whose trade volume stood at $\$ 3.91$ trillion (China Daily 2014). In terms of GDP, China maintained the second largest economy ( $\$ 10.35$ trillion in 2014) following the U.S. (\$17.42 trillion in 2014), as it surpassed Germany in 2007 and Japan in 2010 (World Bank 2015).

With this rapidly growing economy, China converted its economic capabilities into military power. In 2014, China spent $\$ 190.9$ billion on military expenditures, the second largest military budget in the world behind the United States-\$577.5 billion (SIPRI 2014). With its enhanced economic and military confidence, in the early 2010s, China began to take more assertive actions in addressing the South China Sea and East China Sea maritime disputes (Denyer 2014). China claimed sovereignty over almost all of the South China Sea based on the so-called "nine dashed lines" (Keyuan 2012; O’Rourke 2014). The Chinese navy dispatched patrol vessels to the disputed areas more often than before, heightening tensions with neighboring countries such as Vietnam and the Philippines. In November 2013, the Chinese government declared a new Air Defense Identification Zone (ADIZ) that included the sky over the Senkaku/Diaoyu islands, while conducting far more frequent patrols in this disputed area (Osawa 2013).

These assertions prompted the Obama administration to address the rise of China more actively. The U.S. pivot to Asia strategy includes military, diplomatic, and economic dimensions. Washington has augmented its military presence in Asia in order to maintain the U.S.-centered world order established in the wake of World War II, despite significantly decreasing its overall military budget (Plumer 2013). In November 2011, the U.S. and Australia made an agreement to deploy 2,500 U.S. marines in Australia, which was a strategy to confront more directly the challenge posed by China's rapid advance as an economic and military power (Calmes 2011). In June 2012, Obama announced that he would 
deploy as many as four littoral combat ships to Singapore starting with 2013 (Huxley 2012).

Furthermore, in the "two-plus-two" meeting held in October 2013, the foreign affairs and defense chiefs of the U.S. and Japan agreed to revise the bilateral defense cooperation guidelines by the end of 2014, in order to address rising threats in the Asia-Pacific region (Aoki 2013). They promised to enhance cooperation in ballistic missile defense, cyber security, and the safe use of space. As a result of eight rounds of negotiations, in April 2014, the U.S. and the Philippines signed the Enhanced Defense Cooperation Agreement (EDCA) to settle international disputes by peaceful means under both the charter of the United Nations and the 1951 Mutual Defense Treaty (Thayer 2014). Furthermore, Hilary Clinton visited Myanmar, a first for an American Secretary of State in more than half a century, in order to restore its relationship with one of the most isolated and authoritarian nations (Lee 2011). In 2012, the U.S. and Vietnam, former Cold War foes, also reached an agreement to deepen their military ties in five key areas, including maritime security, search and rescue, and peacekeeping operations (Muñoz 2012).

On top of these policy measures, the U.S. also sought to strengthen the U.S.-ROK-Japan security triangle to keep in check and balance a rising China. To this end, two strategies were adopted. The first was to build a ballistic missile defense (BMD) system in East Asia that could significantly weaken China's missile attack capabilities and defend against North Korean nuclear and missile threats. Since the mid-2000s, the U.S. has striven to persuade Japan and the ROK to participate in the establishment of a U.S.-led BMD system. As a result, Japan became an enthusiastic participant in U.S.-led BMD efforts while South Korea was reluctant to join in due to China's strong objections. Seoul has instead maintained "an independent BMD capability that is not tied to the U.S. regional BMD architecture," although deciding to deploy the Terminal High Altitude Area Defense (THAAD) system to counter the growing military threat posed by North Korea (Kelly 2015; Fabey 2017; Kai 2017; Roehrig 2019).4

The second strategy was to draft the General Security of Military Information Agreement (GSOMIA) between the ROK and Japan, which provides a legal framework for the two states to share and protect classified military information (Chae 2012). The signing of the GSOMIA could contribute to the strengthening of the U.S.-ROK-Japan security triangle by increasing the sharing of classified

4 Because of China's staunch resistance, the Moon Jae-in government eventually agreed to "the three no's: no further THAAD deployments, no participation in the U.S. BMD system, and no trilateral military alliance with the United States and Japan." 
military information. The South Korean and Japanese governments were scheduled to sign the military intelligence pact in June 2012, but they put it on hold due to the outcry of the Koreans, who still had strong historical anti-Japanese sentiments coupled with misgivings over Japan's remilitarization (Kwon 2012; Park and Yun 2016). ${ }^{5}$

The United States also developed a new military operational concept-Air-Sea Battle-as a means of coping with China's anti-access and area-denial (A2/AD) capabilities. The People's Liberation Army (PLA) embraced the idea that, in order to avoid defeat, the PLA should be able to strike U.S. forces before they can attack Chinese forces. Under this assumption, the PLA made every effort to increase "A2/AD capabilities to swiftly take out U.S. carriers, air bases, and command, control, communications, computers, intelligence, surveillance and reconnaissance (C4ISR) networks" (Gompert and Libicki 2014). As a result of China's commitment to A2/AD capabilities, the vulnerability of the U.S. forces grew significantly, thereby leading to the development of the Air-Sea Battle concept. This strategy tries to develop networked and integrated forces capable of disrupting, destroying, and defeating enemy forces across air, land, sea, space, and cybernetic domains. To accomplish this, the U.S. Navy and Air Force will use both conventional and cyber-warfare attacks on China's A2/AD "kill chain" of sensors, networks, launchers, weapons, and command and control centers. For maximizing Air-Sea Battle strategy, the U.S. forces are necessary to attack China's $\mathrm{A} 2 / \mathrm{AD}$ kill chain before it can be used against them.

In addition to these military/security measures, the United States balanced the economic challenge from China. The annual flow of U.S. investment into East Asia increased from $\$ 22.5$ billion in 2009 to $\$ 41.4$ billion in 2011. U.S. exports to the Asia-Pacific region totaled more than $\$ 320$ billion in 2012, a growth of nearly eight percent since 2008 (Sutter et al 2013). The U.S. also tried to make a Trans-Pacific Partnership (TPP) agreement with eleven Asia-Pacific countries, including Japan, Vietnam, Malaysia, and Australia, in order to "position the U.S. as a major economic actor in Asia and reinforcing its global dominance and extending its sphere of influence into China's front and back yards."(Smith 2014)

The TPP, part of the economic dimension of the U.S. "pivot to Asia," is a free trade deal designed to remove tariffs on goods and services, tear down a host of non-tariff barriers and harmonize various regulations. In June 2005, only four countries (Brunei, Chile, New Zealand and Singapore) singed the original agreement, but in 2008, five additional countries (Australia, Malaysia, Peru, the

${ }^{5}$ In November 2016, South Korea and Japan finally sealed the controversial intelligencesharing deal, GSOMIA, which was primarily led by the Obama administration. 
U.S., and Vietnam) began negotiations to join the group (Yuan 2012). The U.S. took the lead in 2009 as part of its economic rebalancing in Asia (Solis 2013). ${ }^{6}$ In an article published in People's Daily, Ding Gang, a prominent journalist specializing in international affairs, states that "the U.S. does not want to be squeezed out of the Asia-Pacific region by China $\cdots$ (the) TPP is superficially an economic agreement but contains an obvious political purpose to constrain China's rise." (Yuan 2012) The U.S. also increased its foreign aid to the Asia-Pacific region by seven percent. This was another element of Washington's effort to strengthen its multidimensional economic ties with the region (Williams 2013).

\section{CHINA'S WEDGE STRATEGY}

Facing such a U.S. rebalancing strategy, China tried to draw the ROK into its camp and to drive a wedge in the U.S.-ROK-Japan security triangle. The creation of a historical alliance between China and South Korea, which share a common historical antagonism toward Japan, can serve as a means of weakening the trilateral relationship, thus offsetting U.S. rebalancing attempts in Asia.

One of the most significant wedge strategies that China took was President Xi Jinping's state visit to South Korea, a vital U.S. ally, in July 2014. Chinese leaders usually visited their ally, North Korea, before visiting South Korea. Instead, Xi traveled to Seoul first and embraced ROK President Park Geun-hye, showing Beijing's ambitions to undermine the United States. This move appeared to signal his resolve to weaken America's alliances in Northeast Asia and fortify his vision of a new security architecture in the region, with China as the dominant player (Perlez 2014). According to an interview with an expert in South Korea, Xi's visit to Seoul would start a process of testing close U.S. ties with South Korea and Japan, which Beijing believes have been meant to check its rise (Koh 2014).

The two leaders had widely been expected to express their shared concerns over Japan's military resurgence following the summit talks in Seoul, but no such statement was made public. The Joint Statement issued after the summit talks did not even mention Japan-related issues (Ishida and Kaise 2014). However, Xi highlighted Japan's brutality against China and South Korea in the last century in an address at Seoul National University. He stated, "Our two countries had suffered tremendously when (Japan) launched its barbarous aggression on China and Korea and annexed and occupied the Korean Peninsula in the first half of the

6 As part of its America first strategy, in January 2017 the U.S. Donald Trump administration adopted a protectionist policy, thus withdrawing from the multilateral TPP agreement in order to "promote American industry, protect American workers, and raise American wages." (Blackwill and Rappleye 2017) 
20th century. When the war against Japan was at its highest pitch, the Chinese and Korean people shared their suffering and helped each other through sweat and blood." He also noted that, in the late 16th century, a Chinese dynasty sent troops to help a Korean dynasty defeat invading Japanese troops. "Both countries' nationals $\cdots$ walked shoulder to shoulder to battle grounds, together, 400 years ago." (Kim 2014) President Xi stressed the joint suffering of China and South Korea under twentieth-century Japanese militarism during his visit. During a special luncheon hosted by Park on the final day of Xi's state visit, "Xi and Park also agreed that it is worrying that Japan's attitude toward revising history continues as it even seeks to expand its right to self-defense." The two leaders also agreed on the fact that "it is regrettable that Japan appears to be attempting to damage and play down the Kono Statement in practice, even though it has said it will inherit it." (Yonhap News Agency 2014a)

Obviously, China tried to entice South Korea into its camp, to challenge Japan on differences over historical perceptions, including the wartime "comfort women" issue. "On the issue of comfort women, both countries will cooperate in joint studies, sharing and donating materials to each other," said an attachment to a joint statement issued after the summit meeting (Ishida and Kaise 2014). However, Japanese government officials expressed concern that South Korea "will be taken into China's camp by agreeing to engage in joint studies." Xi then proposed to "celebrate" Liberation Day, which traditionally in East Asia falls on August 15, the date when Asian countries were liberated from the Japanese invasion and rule. In response to Xi's proposal, at a press conference in Tokyo, Chief Cabinet Secretary Yoshihide Suga said that "any attempt by China and South Korea to coordinate in picking apart past history unnecessarily and making it an international issue is utterly unhelpful for building peace and cooperation in the region.” (The Japan Times 2014)

Furthermore, Xi and the South Korea National Assembly Speaker, Jung Eui-hwa, shared the idea of a "Korea-China-Japan joint history research committee." The committee's goal would be the creation of a joint textbook among the three nations. In a meeting with Xi, Jung asked, "For the bright future of Northeast Asia, a shared awareness of history is important. What do you think about establishing a Korea-China-Japan joint history research committee for the long-term creation of a 'joint textbook'?" Xi gave a positively worded response, replying, "A joint history research committee, as suggested, would play an active role in establishing accurate history among the three nations." He went on saying, "China and Korea both have similar interests and experiences regarding Japan's historical issues. Last August, China's National People's Congress (NPC) and Korea's National Assembly announced a joint statement requesting Japan to 
sincerely apologize for their history of invasions and colonial rule. This yielded positive results in forming long-term cooperative relationships with neighboring countries.” (Han 2014)

\section{AHN JUNG-GEUN MEMORIAL MUSEUM}

China was leading the charge to win South Korea's cooperation in putting up a united front against Japan on other divisive historical issues. For example, in June 2013, Park asked Xi to erect a monument for An Jung-geun at the Harbin railway station in northeastern China, the place where, in 1909, the Korean independence activist-An Jung-geun-assassinated Japan's first prime minister, Ito Hirobumi. China not only obliged, but went a step further. In January 2014, China opened a huge memorial hall there for Ahn, who is regarded as a national hero in South Korea. In addition, China erected a stone monument to mark the stronghold of exiled Korean soldiers who fought against Japan's colonial rule of the Korean Peninsula. The memorial hall in Harbin Station displays diverse historical data on the incident, including Ahn's pictures and relevant documents (Yonhap News Agency 2014b).

China's action reflected its desire to work jointly with South Korea against Japan's understanding of its own wartime past. China had been uneasy about requests to commemorate Ahn to avoid antagonizing Japan. In 2006, a bronze statue of Ahn was set up near the station at the proposal of a South Korean group, but local authorities removed it two weeks later on the grounds that statues of foreigners were not permitted. According to the media, "Consideration for relations with Japan ruled out such a monument." (BBC News 2014) However, several years later, China said that Ahn was a "famous anti-Japanese high-minded person.”(BBC News 2014) Sino-Japanese ties have since soured sharply, particularly over the Japanese administered Senkaku/Diaoyu Islands in the East China Sea. This time, Abe's visit to the Yaskuni Shrine was apparently a clincher for Beijing, which continues to criticize him as a hard-liner toward China. Both China and South Korea consider the Yasukuni Shrine a symbol of Japan's past militarism because it honors 14 Class-A war criminals among the war casualties. The construction of the memorial for Ahn, who is regarded by the Japanese government as a criminal, reflects the high value that China places on South Korea as a partner in historical issues.

A Japanese government spokesman, again, branded Ahn a "terrorist" after the Memorial hall opened. Yoshihide Suga said that the exhibit was "extremely regrettable $\cdots$ the coordinated move by China and South Korea based on a one-sided view is not conductive to building peace and stability." (BBC News 2014) On the other hand, South Korea's foreign ministry said Ahn was a "widely 
respected figure", describing the assassination as a "courageous act." He also said "they hoped the museum would set the path for genuine peace and cooperation based on correct historical awareness.” (BBC News 2014) Moreover, a delegation of South Korean congressmen held a ceremony to mark the 104th anniversary of the execution by the Japanese of Ahn Jung-geun. He was executed in a Japanese prison in Lushun district in the city of Dalian. About 200 people, including the South Korean delegation led by Rep. Suh Chung-won of the ruling Saenuri Party, attended the ceremony (Yonhap News Agency 2014c). Furthermore, in December 2015, China opened its first museum dedicated to former comfort women in Nanjing.

\section{FEELING DISCOMFORT?}

Washington remained confident that despite problems between Japan and South Korea, its relationship with Seoul was on solid footing. Mr. Revere, a former Deputy Secretary of State for East Asia and the Pacific, said, "This is another effort by China to not so subtly send a message to the United States that it is looking to reshape the region and it is willing to throw its weight around in ways that demonstrate China is the major player." Mr. Revere added that the effort to "drive a wedge between South Korea and the U.S. is not going anywhere." (Perlez 2014) Moreover, regarding the rightward shift of Japan, the U.S. clarified its support for Japan's pursuit of the right of collective self-defense. "The United States welcomes Japan's new policy regarding the right of collective self-defense," Defense Secretary Chuck Hagel stated on July 1, 2014, adding, "This will allow the Self-Defense Forces' participation in a wider variety of operations and add to the efficiency of the US-Japan alliance.” (Business Korea 2014)

\section{ROK'S HEDGING}

As noted before, South Korea was sandwiched in between the U.S.'s rebalancing acts and China's wedge strategies in the East Asian region. The U.S. continually urged the ROK government to join the U.S.-led missile defense system, which primarily aims at balancing the growing Chinese missile attack capabilities. To strengthen the U.S.-ROK-Japan security triangle, the U.S. also prompted the South Korean government to sign the General Security of Military Information Agreement (GSOMIA) with Japan. The most symbolic event that showed U.S. pressure on the ROK government regarding these issues was the remark made by U.S. Vice President Biden in December 2013, when he met ROK President Park in Blue House. Biden said, "It has never been a good bet to bet against America. And America is going to continue to place its bet on South Korea." ? This remark 
can be interpreted as a warning message for the ROK not to lean toward China too much.

Facing such an American rebalancing strategy, China attempted to drive a wedge in the U.S.-ROK-Japan security triangle by enticing South Korea into the Chinese camp. In other words, China sought to make a historical alliance with the ROK that aims at uniting against their common historical adversary-Japan. Factors that show the forging of the historical alliance between Beijing and Seoul are as follows. First, Beijing joined Seoul in harshly blaming Tokyo for its unapologetic stance on past misdeeds, including sexual slavery and forced labor. Second, the Chinese government was very eager to establish (and/or renovate) a memorial in China for Ahn Jung-geun, who had, in 1909, assassinated Ito Hirobumi, the first Prime Minister of Japan and former Resident-General of Korea. Third, South Korean President Park Guen-hye was given an exceptionally warm reception from the Chinese President Xi Jinping when she paid a state visit to China in June 2013. Furthermore, in an unprecedented action, in July 2014, President Xi visited South Korea before going to North Korea, which has been China's traditional ally. Xi's visit to the ROK sent a clear message that South Korea should not see the United States as its only future ally.

To cope with this dilemma, the ROK government adopted a hedging strategythat is, working with both sides-as opposed to betting on only one of the two superpowers. Seoul augmented its economic and "historical" cooperation with Beijing, while continuing its close security ties with Washington. Although the U.S. and the ROK are long-term security allies, South Korea cannot completely follow the U.S. rebalancing strategy for two reasons. First, it would be implausible for the ROK to provoke China by solely siding with the U.S., because the PRC has significant influence on the South Korean economy, North Korean nuclear threats, and even future Korean reunification. Second, the South Korean government has a strong antagonism toward the Japanese Prime Minister Abe Shinzo and his government's historical revisionism. After he came to office in December 2012, Abe continuously instituted provocative history policies, significantly souring the South Korea-Japan relationship. Among them were the adoption of more nationalist history textbooks, his review and tarnishing of the Kono statement, which for the first time acknowledged Japan's forced mobilization of comfort women during World War II, and his reinterpretation of Article 9 of the "Peace Constitution," on the right of collective self-defense.

Seoul seemingly knew that President Xi's goal was to separate Seoul's security

7 Accessed at http://www.whitehouse.gov/the-press-office/2013/12/o6/remarks-vice-presid ent-joe-biden-and-republic-korea-president-park-geun- (July 12, 2014) 
provider-the U.S.-from South Korea, where nearly 30,000 American troops are based (Perlez 2014). To China, South Korea was a key U.S. military ally in the region and exploiting any rift between them would have helped China in countering U.S. President Barack Obama's strategic "pivot" to Asia. That is one of the reasons that President Park used ambiguous expressions in dealing with China. She responded to Xi's offer to jointly hold memorial activities in 2015 to mark the 70th anniversary of the Korean Peninsula's liberation from Japanese colonial rule at the end of WWII, saying that South Korea also plans to hold "meaningful events" (Yonhap News Agency 2014c).

Such a "pro-China, anti-Japan" stance was part of South Korean diplomatic efforts in the face of complex dynamics in Northeast Asia. According to one diplomatic source, "Such a direction is not the picture South Korea wants, and it is not the ultimate diplomatic goal either. It is only one aspect which has been temporarily captured." (Kyunghyang News 2013) The problem is deeply related to the American influence in Northeast Asia. The United States' attempt to keep China in check by strengthening security cooperation with South Korea and Japan is the primary cause of South Korea's latest diplomatic actions. Behind that, though, lies South Korea's risky "tightrope diplomacy" caught between the U.S. and China. China is deliberately trying to narrow its distance with South Korea in response to the U.S. efforts to keep Beijing in check. Meanwhile, South Korea cannot just watch as Japan, with some help from the U.S., charges toward becoming a military power while veering to the right politically, without any reflection on its past history. Nor can Seoul oppose the U.S. and put the brakes on the situation. At the same time, South Korea must avoid actively strengthening its cooperation with the U.S. and Japan so as to not provoke China.

\section{CONCLUSION WITH IMPLICATIONS AND PROSPECTS}

As analyzed thus far, the major powers in East Asia adopted starkly different strategies for their own national interests during the 2009-2015 period. This period is important because it witnessed the emergence of more complex geopolitical strategies in East Asia, which contributed to the recently unstable East Asian regional order. Furthermore, analyzing the time period can promote our understanding of the nature of recent conflicts and tensions in Trump-Xi era, based on Obama-Xi relations.

In sum, responding to a more assertive China, the U.S. adopted a rebalancing strategy aimed at preventing China from becoming a dominant power in the East Asian region. As the most important U.S. ally in Asia, Japan felt a serious threat 
from a rapidly rising and more assertive China. Japan thus fully supported the American rebalancing effort by reinterpreting Article 9 of its Peace Constitution and enacting a series of security bills, which enabled Japan to have the right of collective self-defense. On the other hand, China earnestly countered the U.S.-led rebalancing strategy. It continued to enhance its military capabilities, drove a wedge in the U.S.-ROK-Japan security triangle, and established the Asian International Investment Bank (AIIB) and the Regional Comprehensive Economic Partnership (RCEP), both of which exclude the U.S. In addition to this intensifying rivalry between the U.S. and Japan on one side, and China on the other, South Korea began a hedging strategy to work with both sides. Interestingly, since 2015 these clashing geostrategic policies have largely continued other than China's changed strategy from strengthening the China-ROK historical alliance to intimidating South Korea in order to drive a wedge in the U.S.-ROK-Japan security triangle. As shown in the case of THAAD controversy, China openly pressured South Korea not to deploy America's THAAD system on the South Korean soil by imposing harsh economic retaliation (Ku 2019).

As clarified by Figure 2, these clashing strategic choices have ample implications for the East Asian regional order. First, these divergent strategies could lead to catastrophic consequences in East Asia without proper policy coordination. Putting differently, if the U.S. and China continued to compete arduously for hegemonic status in Asia, the two superpowers could get involved in a military conflict. As power transition theory posits (Gilpin 1981), the U.S., which is currently a status quo power in Asia, would strive to not lose its hegemonic status in the region, while China, a rapidly rising power, could take the risk of challenging U.S. supremacy. Under this scenario, the two powerful nations could fall into a conflict at a tipping point, where their power levels become equivalent.

Figure 2. Impact of Clashing Geopolitical Strategies in East Asia

\begin{tabular}{|c|c|c|}
\hline \multicolumn{3}{|c|}{ Growing China's Assertiveness } \\
\hline Military buildup based on rapid economic growth \\
\begin{tabular}{|c|c|c|}
\hline \multicolumn{3}{|c|}{ Clashing geopolitical strategies } \\
\hline US' rebalancing & China's wedge strategy & ROK's hedging \\
\hline \multicolumn{3}{|c|}{ Moving toward unstable condition in East Asia } \\
\hline Intensifying US-China rivarly & Continuous Sino-Japanese tension & Persistent ROK-Japan antagonism \\
\hline
\end{tabular}
\end{tabular}


A most symbolic issue that might trigger such a tragic incident would be the South China Sea maritime disputes. Both China and the U.S. would not retract from their contrary positions. It appears difficult for them to reach a compromise to resolve the issue peacefully. China staunchly claims sovereignty over almost all of the South China Sea based on the U-shaped lines, which have not been recognized according to international law. China has dispatched its coast guard ships to the contentious area more frequently and has even created artificial islands to support its claims, despite strong protests and resistance from the U.S. and ASEAN countries, such as Vietnam and the Philippines. From the U.S. perspective, China definitely violates international law, especially the UN Convention on the Law of Sea (UNCLOS), which was signed and ratified by China, as well as many other nations. To warn China of its provocative actions, President Obama had allowed U.S. warships to maneuver inside the contentious area. As some experts warn, these actions taken by the two great powers could unintentionally spark a skirmish. If that happens, an all-out war cannot be excluded as a possible outcome. It would be difficult for either the U.S. or China to back down, because this issue is closely linked with national status or reputation in international politics (White 2012).

Second, the intensifying U.S.-China rivalry might have a negative impact on the peace and security in the East Asian region. As discussed before, in late 2011, the Obama administration declared a U.S. "pivot to Asia" (later renamed as a U.S. "rebalance" to Asia), preventing China from taking a dominant position in the region. Using military, economic, and diplomatic measures, the U.S. sought to encircle China. In this process, Japan, which has serious concerns over a rising China, with whom it has historical/territorial disputes, became a much stronger U.S. ally to check and balance this threat. Indeed, the U.S. government has long pressured Japan to take a more proactive role in international security matters alongside U.S. military forces. Therefore, starting with the early 2010s, the U.S. and Japan came to have very similar national interests vis-à-vis China.

This phenomenon has adversely affected the East Asian peace, security, and reconciliation. With solid American support, the conservative Japanese government, which has not successfully come to terms with its past misdeeds, took a very nationalistic stance on its past history and even reinterpreted Article 9 of the Constitution. Japan also passed a series of security-related laws that make it able to wage war against other nations under the right of collective self-defense. These acts further aggravated Japan's relations with its neighbors, especially China and South Korea. In this environment, along with the U.S.-China rivalry, the China-Japan rivalry has intensified. South Korea and Japan, both of which have democratic rule and a free market economy as well as allied relationships 
with the U.S., maintain a highly antagonistic relationship. Therefore, it is becoming harder for the major powers in East Asia to achieve genuine reconciliation and construct a peaceful East Asian community.

Considering all these aspects, we believe that the U.S. and China should find a suitable approach to avoid the intensification of their rivalry and to maximize mutual cooperation in dealing with the many challenging global issues instead, such as pandemics, nuclear proliferation, the war on terror, global economic/ financial stability, and climate change. More precisely, in order to make this happen, China should make great efforts to resolve its territorial disputes with neighboring countries, using international law and/or multilateral institutions. The U.S. should concurrently take the risk of losing its dominant influence in the East Asian region. In other words, the U.S. needs to consider sharing power with China, as claimed by political scientist Hugh White (2012). It seems difficult for current American leaders to choose this option, because the U.S. has not had such an experience since it became a superpower in the wake of World War II. During the Cold War period, the U.S. successfully challenged and contained the Soviet Union. Although power-sharing is not an easy option, this strategy seems better than continual competition for hegemony in East Asia, which could result in mutual destruction.

We also consider that the hedge strategy is the most appropriate policy for South Korea. As a middle power, South Korea is faced with a problem of striking a balance between two powerful nations. Making the right choice between Washington and Beijing is vital to protect Seoul's national interests. The U.S. and China may want South Korea to make a clear allegiance, but for Seoul's own interests, choosing one over the other poses a huge risk. The U.S. is still indispensable to South Korea's security, while China is South Korea's most important economic partner. China is also a key player that could help resolve the continually complicated North Korean nuclear issue and achieve a peaceful Korean reunification. Thus, Seoul needs to be flexible when responding to both Washington and Beijing, through making the most of so-called "maneuvering" strategies. If U.S.-China tensions worsen further, and South Korea should be forced to take a side, a different response would be necessary. However, until then, it should be possible to respond flexibly to both powers while securing South Korea's position in international politics and obtaining the necessary independence to make its own policy choices. South Korea should not repeat the same mistakes it made in the early 20th century by hastily leaning to one side, but it should skillfully use the hedge strategy to its own advantage.

Since the Trump administration set sail in January 2017, it has been emphasizing "America First," and "Peace through strength" while implementing 
strategies that check and pressure China. In addition to launching a trade war with China, President Trump presented a free and open Indo-Pacific (FOIP) vision, which emphasizes such goals as "free, fair, and reciprocal trade, open investment environments, good governance, and freedom of the seas" in the Indo-Pacific (Pompeo 2019). FOIP needs to be further developed as a concrete U.S.' Asia strategy, but its main purpose is to check and balance China, particularly to create alternatives to China's Belt and Road Initiative (Poling 2019). As a result, what followed was increased strategic competition between the U.S. and China, which brought deep uncertainties and instability to regional and international order. During the Trump-Xi era, the two countries are coming at each other head-to-head due to 'strategic distrust'. Such rivalry has manifested in the realms of trade, cyber security, and technological competition such as artificial intelligence, robotics, and $5 \mathrm{G}$ network.

Nevertheless, there are still limitations to analyzing that the recent trade and cyber/technological disputes between the two great powers will amplify into a hegemonic conflict disputing over security and military issues. This is because the U.S. and China are deeply interconnected with each other in the economic realm while dealing with common global challenges, including the current COVID-19 pandemic, North Korea's nuclear/missile provocations, climate change, and war on terrorism. Hence, the two great powers are required to have strategic cooperation to cope with such hard challenges. In this regard, before U.S.-China ties display a momentum of full-fledged conflict, South Korea needs to maintain strategic patience, as noted before. There is a low chance that their strategic rivalry will lead to a large-scale military conflict. Given these circumstances, therefore, South Korea should continue to adopt a 'wait-and-see' strategy as a diplomacy option while making every effort to minimize negative effects that may arise from taking the 'strategic ambiguity' through proactive dialogue and cooperation as well as an objective analysis of external threat and national interests (Shin 2018, 2; Kim 2018; Park 2019).

\section{REFERENCES}

Aoki, Mizuho. 2013. “U.S., Japan to update defense rules in 2014: First 'two-plus-two' parley in Tokyo focuses on rising threats in Asia." Japan Times (October 3). Accessed at https://www.japantimes.co.jp/news/2013/10/03/national/pol itics-diplomacy/u-s-japan-to-update-defense-rules-in-2014/\#.XiXlCGgzZ PY (June 23, 2014). 
BBC News. 2014. "Japan protest over Korean assassin Ahn Jung-geun memorial in China." BBC News (January 20). Accessed at https://www.bbc.com/ news/world-asia-25808437 (February 11, 2017).

Blackwill, Robert D. and Theodore Rappleye. 2017. "Trump's Five Mistaken Reas ons for Withdrawing from the Trans-Pacific Partership.” Foreign Policy (June 22). Accessed at https://foreignpolicy.com/2017/06/22/trumps-fivemistaken-reasons-for-withdrawing-from-the-trans-pacific-partnershipchina-trade-economics/ (January 28, 2020).

Brooks, Stephen G. and William C. Wohlforth. 2008. World out of Balance. Princeton: Princeton University Press, 22.

Business Korea. 2014. "Pyongyang, Washington, Tokyo Feeling Discomfort at Presid ent Xi Jinping's Visit to Seoul." (July 3). Accessed at http://www.businessko rea.co.kr/news/articleView.html?idxno=5292 (July 11, 2014).

Calmes, Jackie. 2011. "A U.S. Marine Base for Australia Irritates China." The New York Times (November 16). Accessed at https://www.nytimes.com/2011/ 11/17/world/asia/obama-and-gillard-expand-us-australia-military-ties.h tml (June 23, 2014).

Cha, Victor D. 1999. Alignment Despite Antagonism: The US-Korea-Japan Security Triangle. Stanford, CA: Stanford University Press.

Chen Dingding and Xiaoyu Pu. 2014. "Correspondence: Debating China's Assertiveness.” International Security 38(3), 176-183.

China Daily. 2014. “Top 10 trading partners of the Chinese mainland.” Chinadaily.co $m$ (February 19). Accessed at http://www.chinadaily.com.cn/bizchina/20 14-02/19/content_17290565.htm (November 12, 2014).

Choe, Sang-hun. 2012. "South Korea to sign military pact with Japan." The New York Times (June 28). Accessed at https://www.nytimes.com/2012/06/ 29/world/asia/south-korea-to-sign-historic-military-pact-with-japan.ht $\mathrm{ml}$ (July 2, 2014).

Christensen, Thomas J. 2011. "The Advantages of an Assertive China." Foreign Affairs 90(2), 54-58.

Crawford, Timothy W. 2008. "Wedge Strategy, Balancing, and the Deviant Case of Spain, 1940-41.” Security Studies 17(1), 3. . 2011. "Preventing Enemy Coalitions: How Wedge Strategies Shape Power Politics.” International Security35(4), 156.

Denyer, Simon. 2014. "China's rise and Asian tensions send U.S. relations into downward spiral." The Washington Post (July 7). Accessed at https:// www.washingtonpost.com/world/asia_pacific/chinas-rise-and-asian-te nsions-send-us-relations-into-downward-spiral/2014/07/07/f371cfaa-d5 cd-4dd2-925c-246c099f04ed_story.html (July 29, 2014). 
Gilpin, Robert. 1981. War and Change in World Politics. Cambridge, U.K.: Cambridge University Press.

Gompert David C. and Martin Libicki. 2014. "Cyber Warfare and Sino-American Crisis Instability.” Survival56(4), 8.

Gordon, Bernard K. 2014. "Bring China into TPP.” The National Interest (April 11). Accessed at https://nationalinterest.org/commentary/bring-china-tpp10227 (July 2, 2014).

Han, Seoung-jin. 2014. "Xi positive about Korea-China-Japan joint history research.” The Korea Times (July 4). Accessed at http://www.korea times.co.kr/www/nation/2017/11/113_160451.html (March 3, 2017).

Hemmings, John. 2013. "Hedging: The Real US policy Towards China?" The Diplomat (May 13). Accessed at https://thediplomat.com/2013/05/hedg ing-the-real-u-s-policy-towards-china/ (February 11, 2017).

Huxley, Tim. 2012. "Singapore and the US: not quite allies." The Strategist(July 30). Accessed at https://www.aspistrategist.org.au/singapore-and-the-us-notquite-allies/ (June 23, 2014).

Ishida, Koichiro and Akihiko Kaise. 2014. "Insight: China moving to bring South Korea into its sphere of influence." The Asahi Shimbun (July 4).

Jackson, Van. 2014. "Power, trust, and network complexity: three logics of hedging in Asian security." International Relations of the Asia-Pacific 14(3), 333.

Johnston, Alstair Ian. 2013. "How New and Assertive is China's New Assertiveness?” International Security 37(4), 7-48.

Kelly, Robert E. 2015. "South Korea's THAAD Decision.” The Diplomat(April 13). Accessed at https://thediplomat.com/2015/04/south-koreas-thaad-decision/ (May 25, 2015).

Keyuan, Zou. 2012. "China's U-Shaped Line in the South China Sea Revisited." Ocean Development \& International Law 43, 18-34.

Kim, Gang-nyung. 2018. "The Development of the U.S.-China Relationship, Pending Issues and Implications.” Korea and International Society2(2), 89-130.

Kim, Hyung-Jin. 2014. "Xi rebukes Japan for brutality in China, Koreas.” The Associated Press (July 4). Accessed at https://www.sandiegouniontribu ne.com/sdut-xi-rebukes-japan-for-brutality-in-china-koreas-2014jul04-s tory.html (March 5, 2017).

Koh, Yu-hwan. 2014. "Chinese leader's Seoul visit snubs North Korea.” The Asahi Shimbun (July 3).

$\mathrm{Ku}$, Yangmo. 2019. "Privatized Foreign Policy? Explaining the Park Geun-hye Administration's Decision-Making Process,” Korea Journal59(1), 106-134. 
Kwon, K.J. 2012. "South Korea and Japan put military intelligence pact on hold after outcry." CNN (June 29). Accessed at https://edition.cnn.com/2012/ 06/29/world/asia/south-korea-japan-pact/index.html (July 2, 2014).

Kyunghyang News. 2013. "Behind the "Pro-China, Anti-Japan" curtain, President Park walks a Tightrope between the U.S. and China." Kyunghyang News (October 10).

Lee, Matthew. 2011. "Hillary Rodham Clinton Makes Historic Visit To Myanmar," The Huffington Post (November 30).

Lee, Samuel. 2014. "Why wouldn't S. Korea want U.S. missile defenses?" CBS News (June 3). Accessed at https://www.cbsnews.com/news/u-s-propo ses-advanced-missile-defense-system-in-south-korea/(April 6, 2018).

Martin, Susan B. 2003. "From Balance of Power to Balancing Behavior: The Long and Winding Road." in Perspectives on Structural Realism, ed. Andrew K. Hanami Palgrave-Macmillan, 70.

Muñoz, Carlo. 2012. "US, Vietnam defense chiefs reach deal to strengthen military ties." The Hill (June 4). Accessed at https://thehill.com/policy/ defense/230677-us-vietnam-strengthen-military-ties (June 23, 2014)

O'Rourke, Ronald. 2014. "Maritime Territorial and Exclusive Economic Zone (EEZ) Disputes Involving China: Issues for Congress.” Congressional Research Service (March 14).

Osawa, Jun. 2013. "China’s ADIZ over the East China Sea: A 'Great Wall in the Sky'?” Brookings Opinion (December 17). Accessed at https://www. brookings.edu/opinions/chinas-adiz-over-the-east-china-sea-a-great-wa 1l-in-the-sky/(July 1, 2014).

Pape, Robert A. 2005. "Soft Balancing against the United States." International Security30(1), 7.

Park, Byung-gwang. 2019. "Recent U.S.-China Dispute and Direction of Korean Response.” Issue Brief (August 19). Seoul: Asan Institute for Policy Studies.

Park, Jaehan and Sangyound Yun. 2016. "Korea and Japan's Military Information Agreement: A Final Touch for the Pivot," The Diplomat (November 24). Accessed at https://thediplomat.com/2016/11/korea-and-japans-military -information-agreement-a-final-touch-for-the-pivot/(January 15, 2017).

Park, Jae Jeok. 2011. "The US-led alliances in the Asia-Pacific: hedge against potential threats or an undesirable multilateral security order." The Pacific Review 24(2), 139-40.

Perlez, Jane. 2014. "Chinese President's visit to South Korea is seen as way to weaken US alliances." The New York Times (July 2). Accessed at https://www.nytimes.com/2014/07/03/world/asia/chinas-president-to-vi 
sit-south-korea.html (July 12, 2014).

Plumer, Brad. 2013. "America's staggering defense budget, in charts" The Washington Post (January 7). Accessed at https://www.washingtonpost. com/news/wonk/wp/2013/01/07/everything-chuck-hagel-needs-to-kno w-about-the-defense-budget-in-charts/(November 13, 2014).

Poling, Gregory B. 2019. "For Lack of a Strategy: the Free and Open Indo-Pacific," War on the Rocks (November 13). Accessed at https://warontherocks.com /2019/11/for-lack-of-a-strategy-the-free-and-open-indo-pacific/(April 1, 2020).

Pompeo, Mike. 2019. "A Free and Open Indo-Pacific: Advancing a Shared Vision," U.S. Department of State (November 4). Accessed at https://www.state.go v/wp-content/uploads/2019/11/Free-and-Open-Indo-Pacific-4Nov2019.p df (April 1, 2020).

Roehrig, Terence. 2019. "Improving Japan-ROK-U.S. Military Cooperation on North Korea: A Tough Road Ahead," Council on Foreign Relations (April 30). Accessed at https://www.cfr.org/blog/improving-japan-rok-us-militarycooperation-north-korea-tough-road-ahead (March 18, 2020).

Saunders, Phillip C. 2014. “China's Role in Asia: Attractive or Assertive?" in David Shambaugh and Michael Yahuda, eds., International Relations of Asia New York: Rowman \& Littlefield, 160-163.

Scobell, Andrew and Scott W. Harold. 2013. "An 'Assertive' China? Insights from Interviews," Asian Security 9(2), 111-31.

Shin, Jong-ho. 2018. 2030 US-China Relations Scenario and Korea Peninsula. Seoul: KINU.

Smith, Jack A. 2014. "The Middle East and the Pivot to Asia: Obama's US Foreign Policy Bait and Switch.” Global Research (June 13). Accessed at https:// www.globalresearch.ca/the-middle-east-and-the-pivot-to-asia-obamasus-foreign-policy-bait-and-switch/5386941 (March 5, 2017).

Solis, Mireya. 2013. “The Containment Fallacy: China and the TPP.” Brookings Up Front (May 24). Accessed at https://www.brookings.edu/blog/up-front /2013/05/24/the-containment-fallacy-china-and-the-tpp/(July 5, 2014).

SIPRI. 2014. "SIPRI Military Expenditure Database." Stockholm International Peace Research Institute (SIPRI). Accessed at http://www.sipri.org/re search/armaments/milex/milex_database/milex_database (December 29, 2014).

Sutter, Robert G., Michael E. Brown, and Timothy J. A. Adamson, with Mike M. Mochizuki and Deepa Ollapally. 2013. Balancing Acts: The U.S. Rebalance and Asia-Pacific Stability. D.C: Sigur Center for Asian Studies.

Thayer, Carl. 2014. "Analyzing the US-Philippians Enhanced Defense 
Cooperation Agreement.” The Diplomat (May 2). Accessed at https:// thediplomat.com/2014/05/analyzing-the-us-philippines-enhanced-defe nse-cooperation-agreement/(June 23, 2014).

The Japan Times. 2014. "Japan hits back at Beijing-Seoul WWII commemoration proposal," The Japan Times (July 4).

The White House. 2013. "Remarks by Vice President Joe Biden and Republic of Korea President Park Geun-Hye in a Bilateral Meeting." The White House (December 6). Accessed at http://www.whitehouse.gov/the-press-office/ 2013/12/06/remarks-vice-president-joe-biden-and-republic-korea-presi dent-park-geun- (July 12, 2014).

Tucker, Nancy Bernkoph. 2013. "The Evolution of U.S.-China Relations," in Tangled Titans: The United States and China, edited by David Shambaugh. Lanham, MD: Rowman \& Littlefield, 35-38.

Waltz, Kenneth N. 1979. Theory of International Politics. McGraw-Hill, 168.

Waltz, Kenneth N. 2008. Realism and International Politics. New York: Routledge, 137.

White, Hugh. 2012. The China Choice: Why We Should Share Power. Oxford: Oxford University Press, 113-124.

Williams, Brock R. 2013. "Trans-Pacific Partnership (TPP) Countries: Comparative Trade and Economic Analysis." Congressional Research Service (June 10).

Wohlforth, William C. and Stuart J. Kaufman and Richard Little. 2007. "Introduction: Balance and Hierarchy in International System." in William C. Wohlforth, Stuart J. Kaufman and Richard Little (eds) The Balance of Power in World History. New York: Palgrave Macmillan, 9-10.

World Bank. 2015. "China." The World Bank. Accessed at http://data.worldbank. org/country/china (March 6, 2017).

Yonhap News Agency. 2014a. "South Korea remembers anti-Japanese martyr in China." Yonhap News Agency (March 26). . 2014b. "Seoul delegation visits China's memorial hall for Korean independence hero." Yonhap News Agency (May 9).

. 2014c. "(Lead) Park, Xi voice concern over Japan's moves to review history, collective self-defense." Yonhap News Agency (July 4).

Yuan, Wen Jin. 2012. "The Trans-Pacific Partnership and China's Corresponding Strategies.” A Freeman Briefing Report, CSIS (June). Accessed at https://www.csis.org/analysis/freeman-briefing-trans-pacific-partners hip-and-chinas-corresponding-strategies (April 6, 2018). 
